\title{
Mycotoxins and Mycotoxicoses, Detection and Analysis: A Review in Retrospect
}

\author{
Ajugwo, G. ${ }^{1 *}$, Opara, U.G. ${ }^{2}$, Wood, T.T. ${ }^{3}$, Akien Alli, I.J. ${ }^{4} \&$ Braide, W. ${ }^{1}$ \\ ${ }^{I^{*}}$ Department of Microbiology, Federal University of Technology, Owerri, Imo State, Nigeria. \\ ${ }^{2}$ Department of Biology/Microbiology, School of Industrial and Applied Sciences, Fedreal Polytechnic, Nekede, Imo State, Nigeria. \\ ${ }^{3}$ National Biotechnology Development Agency, Ajuja, Nigeria. \\ ${ }^{4}$ Science Laboratory Technology, School of Applied Sciences, Kenule Saro-Wiwa Polytechnic, Bori, Rivers State, Nigeria. Email: ajugwogloria@yahoo.com ${ }^{*}$
}

DOI: http://doi.org/10.38177/ajast.2021.5305

Copyright: () 2021 Ajugwo, G. et al. This is an open access article distributed under the terms of the Creative Commons Attribution License, which permits unrestricted use, distribution, and reproduction in any medium, provided the original author and source are credited.

\section{ABSTRACT}

Mycotoxins are recognized as toxic compounds of great concern in the context of human health and economy. Mycotoxins are toxic chemica products formed as secondary metabolites by some fungi that readily colonise crops in the field or after harvest. The toxicity syndrome resulting from the intake of such contaminated material by animal and manis termed Mycotoxicosis. These compounds pose a potential threat to human and animal health through ingestion of food products prepared from these commodities.Mycotoxicoses affect various systems of the body according to the target organs of the mycotoxin. This review revealed the major mycotoxins of fungal origin and their mycotoxicoses. The study also reviewed the history of mycotoxin, methods of mycotoxin detection, analysis and the health implications of consuming mycotoxin-contaminated foods/products. In most developing countries, majority are ignorant of the inherent dangers of consuming mouldy produce or food contaminated with fungi and moulds with possible contamination by mycotoxigenic fungi. In view of this, there is need for general and public education to sensitise the people on the health hazards posed by mycotoxins. Proper washing and cooking practices of food commodities, good agricultural practices, fast and effective analyses and detection, good produce handling and storage are some of the control/regulatory measures that should be encouraged, as to assist in mitigating the side effects of mycotoxins in food and health particularly in the tropical and sub-tropical countries and in African where there is enabling environment that promotes fungal growth.

Keywords: Mycotoxin, Mycotoxicosis, Detection, Analysis, Health impact, Moulds.

\section{Introduction}

Mycotoxins are toxic secondary metabolites produced by toxigenic fungi that infest food and feed materials during pre-and post-harvest periods (Alshannaq, 2017). Mycotoxicology is the branch of mycology that focuses on analyzing and finding out these secondary metabolites produced by fungi, known as mycotoxins. The most commonly encountered dietary mycotoxins with worldwide occurrence are Aflatoxins, Ochratoxins, Zearalenone, Fumonisins, Trichothecenes, Patulin and Ergot Alkaloids, produced by the fungal genera Aspergillus, Penicillium, Fusarium and Clavicep (Pinotti et al., 2016). These are notably deleterious to animals and human beings. Most of the fungi can secrete more than a single mycotoxin, but a given mycotoxin can also be produced by some species that belong to distinct genera. There are certain mycotoxins which have demonstrated acute toxic effects, particularly when consumed at high concentrations, whereas others have toxic effects only after a long-term exposure to lower doses.Effects of chronic exposure include aggravation of disease pathogenesis in experimental animals and humans, reduced animal productivity, and impaired animal nutrition (Kibugu et al., 2009). Mycotoxins can also be teratogenic, carcinogenic, mutagenic, estrogenic, nephrotoxic, hepatotoxic and immunosuppressive in humans and animals (Williams et al., 2004). Mycotoxicoses are the animal diseases caused by mycotoxins (Forgacs and Carll, 1962). While all mycotoxins are of fungal origin, not all toxic compounds produced by fungi are called mycotoxins. The target and the concentration of the metabolite are both important. Fungal products that are mainly toxic to bacteria (such as penicillin) are usually called antibiotics. The majority of mycotoxicoses, result from eating contaminated foods. Skin contact with mold- infested substrates and inhalation of spore-borne toxins are also important sources of exposure (El-Nezami et al., 2002). Except for supportive therapy (e.g., diet, 
hydration), there are almost no treatments for mycotoxin exposure, although Fink-Gremmels (1999), described a few methods for veterinary management of mycotoxicoses, and there is some evidence that some strains of Lactobacillus effectively bind dietary mycotoxins (El-Nezami et al., 1998). Oltipraz, a drug originally used to treat Schistosomiasis, has been tested in Chinese populations environmentally exposed to aflatoxin (Henry et al., 2002). Some fungi are pathogenic to man and are disease causing organisms in humans, some of the diseases caused by them could be fatal if not treated. Such diseases include Aspergillosis Candidiasis, Coccidioidomycosis, Cryptococcosis, Histoplasmosis, Mycetomas, and Paracoccidioidomycosis. Furthermore, immune-compromised people are particularly susceptible to disease by genera such as Aspergillus, Candida, Cryptoccocus (Hube, 2004; Brakhage, 2005), Histoplasma and Pneumocystis (Kauffman, 2007). Many allergic reactions and allergies are caused by fungal spores and fungi from different taxonomic groups (Simon-Nobbe et al., 2008).

A major part of the universal population in all over the world depends on cereals as a main food, and therefore, there is a high risk of mycotoxin. Moreover, mycotoxin contamination can have a large health, financial and social impact, specifically when the incidence of mycotoxin in food commodities is beyond the regulation limits set up by national and transnational establishments. There are various techniques for mycotoxin analysis. These include mainly ELISA test, the lateral flow test, the screening cards, and immunoaffinity columns (Pandy and Arade, 2016). Lately, the emergence of nanotechnology in mycotoxicology is still in its primary stage. Currently, research has been focused on the development of new nanomaterials to inhibit pathogenic fungi and mycotoxins [Abd-Elsalam et al., 2017).

\section{History}

The term mycotoxin was coined in 1962 in the aftermath of an unusual veterinary crisis near London, England, during which approximately 100,000 turkey poults died (Blout, 1961). When this mysterious turkey X disease was linked to a peanut (groundnut) meal contaminated with secondary metabolites from Aspergillus flavus (aflatoxins), it sensitized scientists to the possibility that other occult mold metabolites might be deadly (Forgacs, 1962).Soon, the mycotoxin rubric was extended to include a number of previously known fungal toxins (e.g., the ergot alkaloids), some compounds that had originally been isolated as antibiotics (e.g., patulin), and a number of new secondary metabolites revealed in screens targeted at mycotoxin discovery (e.g., Ochratoxin A). The period between 1960 and 1975 has been termed the Mycotoxin gold rush (Maggon, 1977), because so many scientists joined the well-funded search for these toxigenic agents. Depending on the definition used, and recognizing that most fungal toxins occur in families of chemically related metabolites, some 300 to 400 compounds are now recognized as mycotoxins, of which approximately a dozen groups regularly receive attention as threats to human and animal health (Cole, 1986). Molds (i.e., microfungi) make mycotoxins; mushrooms, other macroscopic fungi make mushroom poisons. The distinction between a mycotoxin and a mushroom poison is based not only on the size of the producing fungus, but also on human intention.

Mycotoxin exposure is almost always accidental. In contrast, with the exception of the victims of a few mycologically accomplished murderers, mushroom poisons are usually ingested by amateur mushroom hunters who have collected, cooked, and eaten what was misidentified as a delectable species (Moss, 1996). 


\section{Major Mycotoxins and Mycotoxicoses}

Mycotoxins are made by fungi and are toxic to vertebrates and other animal groups in low concentrations. Other low-molecular-weight fungal metabolites such as ethanol that are toxic only in high concentrations are not considered mycotoxins (Bennett, 1987). Mycotoxins are not only hard to define; but also challenging to classify due to their diverse chemical structures and biosynthetic origins, their myriad biological effects, and their production by a wide number of different fungal species. Clinicians often arrange them by the organ they affect. Thus, mycotoxins can be classified as hepatotoxins, nephrotoxins, neurotoxins, immunotoxins, and so forth. Cell biologists put them into generic groups such as teratogens, mutagens, carcinogens, and allergens. Organic chemists have attempted to classify them by their chemical structures (e.g., lactones, coumarins); biochemists according to their biosynthetic origins (polyketides, amino acid-derived, etc.); physicians by the illnesses they cause (e.g., St. Anthony's fire, stachybotryotoxicosis), and mycologists by the fungi that produce them (e.g., Aspergillus toxins, Penicillium toxins). None of these classifications is entirely satisfactory. Moreover, as our anthropomorphic focus shifts attention, the same compound may get placed in different cognitive cubbyholes. Aflatoxin, for example, is a hepatotoxic, mutagenic, carcinogenic, difuran-containing, polyketide-derived Aspergillus toxin. Of approximately 500 recognized mycotoxins, only a small variety is documented to motive mycotoxicoses in human and animals. The organs such as liver and kidneys are mostly affected as these are the ones in which mycotoxins are metabolized; however, they may also affect different systems of the body. Historically, acute mycotoxicoses have been common even in mild temperature zones, causing epidemics that devastated entire regions, from time to time influencing the direction of human documents (Bennett and Klich, 2003). Mycotoxicoses occur commonly in tropical regions due to high humidity and temperature required for fungal growth and secretion of mycotoxin (Peraica et al., 2016).

\section{Aflatoxin}

Aflatoxins are chemical metabolites and mycotoxins produced by Aspergillus species of fungi, like A. flavus and A. parasiticus (Adejumo \& Adejoro, 2014; Ashiq, 2015; Martinset al., 2001; Adeyeye, 2016). The four major aflatoxins are called B1, B2, G1, and G2 based on their fluorescence under UV light (blue or green) and relative chromatographic mobility during thin-layer chromatography. Aflatoxin B1 is the most potent natural carcinogen known (Squire, 1981) and is usually the major aflatoxin produced by toxigenic strains. It is also the best studied: in a large percentage of the papers published, Aflatoxins are known as the most important fungal metabolites of a direct health hazard to humans. Aspergillus flavus is widely distributed in soil, air, and rotten plant residues. Aflatoxin production and contamination can take place in the field, in transit, or in storage. However, most infection takes place in the field while aflatoxin production takes place at any point under favourable conditions (Ashiq, 2015; Yin et al., 2008; Martins et al., 2001). Aflatoxins among all the mycotoxins were linked to human diseases such as liver cancer, Reye's syndrome, Indian childhood cirrhosis, chronic gastritis and kwashiorkor in many parts of the world, particularly in African and Asian countries where conditions for growth and storage encouraged fungi and mycotoxin production (Jelinek et al., 1989; Palmgren \& Hayes, 1987; Adeyeye, 2016). Kenya recorded a serious and largest and most acute out- breaks of aflatoxicosis ever documented (CAST, 2003) in 
2004, with 125 dead cases and over 317 others hospitalized for consuming aflatoxin-contaminated maize (Adeyeye, 2016). The nature of the outbreak was due to the consumption of maize contaminated with extremely toxic AFB1 (Aflatoxin B1). The case-control studies carried out by Lewis et al., (2005) showed that the affected people in the area consumed home-grown maize stored under humid conditions. During the outbreak, AFB1 individual daily exposure was 50mg/day (Probst et al., 2007). The diseases caused by aflatoxin consumption are loosely called Aflatoxicoses. Acute aflatoxicosis results in death; chronic aflatoxicosis results in cancer, immune suppression, and other "slow" pathological conditions (Hsieh, 1988). The liver is the primary target organ, with liver damage occurring when poultry, fish, rodents, and nonhuman primates are fed aflatoxin B1. Cytochrome P450 enzymes convert aflatoxins to the reactive 8,9-epoxide form (also referred to as aflatoxin-2,3 epoxide in the older literature), which is capable of binding to both DNA andproteins (Eaton and Groopman, 1994).

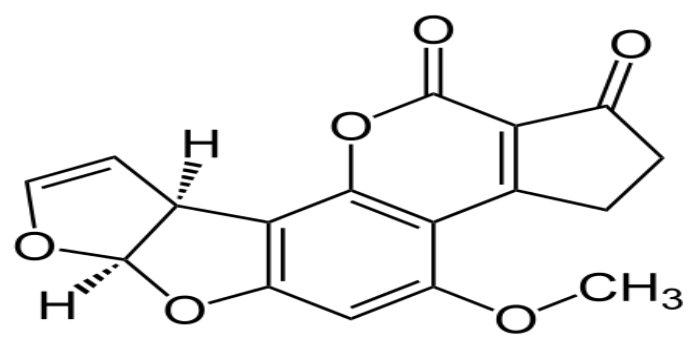

Structure of Aflatoxin $\mathrm{B}_{1}$

\section{Ochratoxins}

Ochratoxin A (OTA) was the first mycotoxic compound isolated from Aspergillus ochraceous, and later it was found in other Aspergillus and Penicillium species such as Penicillium verucosum. There are several OTA analogues, ochratoxins B, C, and alkyl esters of ochratoxins that have similar structure but are less toxic. OTA is the main contaminant of cereals (corn, barley, wheat) and to some extent beans (coffee, soy, and cocoa). The levels of contamination are typically less than $200 \mathrm{ug} / \mathrm{kg}$ (Solfrizzo et al., 2014). OTA is easily absorbed through the gastrointestinal tract mainly in the duodenum and jejunum based on animal studies (Heyndrick et al., 2015). There are no studies on skin or inhalational absorption of OTA. When absorbed, OTA has a high binding affinity for plasma protein. OTA was found in decreasing order of concentrations in kidney, liver, fat, and muscle tissues (Solfrizzo et al., 2014). Excretion is mainly via renal elimination (Rushing and Selim, 2019). The toxicity of OTA involves several mechanisms. OTA inhibits protein synthesis by competing with the phenylalanine aminoacylation reaction catalyzed by Phe-tRNA synthase (Turner et al., 2015). This results in inhibition of protein as well as DNA and RNA synthesis. OTA also disrupts hepatic microsomal calcium homeostasis by impairing the endoplasmic reticulum membrane via lipid peroxidation (Escrivá et al., 2017). Ochratoxin A is the causative agent of kidney diseases (de-generation of proximal tubule cells resulting in interstitial nephritis and hyalinization of glomeruli) in pigs generally referred to as porcine nephropathy (Shephard, 2009). OTA is the major ochratoxin component and is the most toxic among the analogues. However, it has been estimated that an infant could eat up to $10 \mathrm{~kg}$ of food contaminated with $20 \mathrm{ppb}$ without significant adverse health effects (Shephard, 2009). OTA can be analyzed using TLC, HPLC, and ELISA. However, the possibility of cross-reactions cannot be fully ruled out. Other techniques should be used to confirm the levels of OTA (Malir et al., 2016). The tolerance levels for OTA have been 


\section{AJAST}

Asian Journal of Applied Science and Technology (AJAST)

Volume 5, Issue 3, Pages 43-67, July-September 2021

suggested as $1 \mathrm{ug} / \mathrm{kg}$ for infant foods and $5 \mathrm{ug} / \mathrm{kg}$ for cereals (Degen et al., 2018). Both the Food and Agriculture Organization of the United Nations (FAO) and the World Health Organization (WHO) Joint Expert Committee recommends a provisional tolerable weekly intake of 100 microgram $/ \mathrm{kg}$ body weight of OTA (Soto et al., 2015).<smiles>C[C@H]1Cc2c(Cl)cc(C(=O)N[C@@H](Cc3ccccc3)C(=O)O)c(O)c2C(=O)O1</smiles>

Structure of Ochratoxin

\section{Citrinin}

Citrinin was first isolated from Penicillium citrinum prior to World War II (Hetherington and Raistrick, 1931); subsequently, it was identified in over a dozen species of Penicillium and several species of Aspergillus (e.g., Aspergillus terreus and Aspergillus niveus), including certain strains of Penicillium camemberti (used to produce cheese) and Aspergillus oryzae (used to produce sake,miso, and soy sauce) (Manabe, 2001). More recently, citrinin has also been isolated from Monascus ruber and Monascus purpureus, industrial species used to produce red pigments (Blanc et al., 1995). Citrinin has been associated with yellow rice disease in Japan (Blanc et al., 1971). It has also been implicated as a contributor to porcine nephropathy. Citrinin acts as a nephrotoxin in all animal species tested, but its acute toxicity varies in different species (Carlton, 1977).<smiles>CC1=C2C(=CO[C@@H](C)[C@@H]2C)C(O)=C(C(=O)O)C1=O</smiles>

Structure of Citrinin

\section{Ergot Alkaloids}

The human disease acquired by eating cereals infected with ergot sclerotia, usually in the form of bread made from contaminated flour, is called ergotism or St. Anthony's fire. Two forms of ergotism are usually recognized, gangrenous and convulsive. The gangrenous form affects the blood supply to the extremities, while convulsive ergotism affects the central nervous system (Wu, (2013)). Ergotism is caused by Clavicep pupurue. Human ergotism was common in Europe in the middle Ages. For example, a three-volume work entitled Handbook of Geographical and Historical Pathology published in London by August Hirch between 1883 and 1886 recorded 132 epidemicsof European ergotism between the 6th and 18th centuries (Haller, 1993). Matossian (1981) has suggested that the "slow nervous fever" described by the 18th century English physician Jon Huxham may be another example of human ergotism. Slow nervous fever usually occurred in the summer and fall after a severe winter; Huxham suspected "bad food" as the source of the tror uble. Matossian (1989) has also postulated that ergot alkaloids may have had a strong influence on fertility trends in England and other European countries during the $17^{\text {th }}$ and $18^{\text {th }}$ centuries. Modern methods of grain cleaning have almost eliminated ergotism as a human disease. 


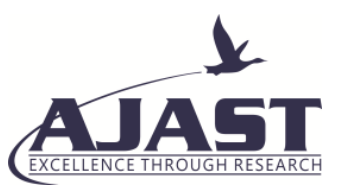

Asian Journal of Applied Science and Technology (AJAST)

Volume 5, Issue 3, Pages 43-67, July-September 2021

Nevertheless, purported ergot poisoning occurred in the French town of Pont-St.-Esprit in 1951 and was the subject of a full-length book treatment, The Day of St. Anthony's Fire (Fuler, 1968). Ergotism is still an important veterinarian problem. The principal animals at risk are cattle, sheep, pigs, and chickens. Clinical symptoms of ergotism in animals include gangrene, abortion, convulsions, suppression of lactation, hypersensitivity, and ataxia (Lorenz, 1979). Sometimes the line between toxin and drug is defined with the shift of a decimal point or a change in a small chemical moiety. The ergot alkaloids are a case in point. Their myriad actions have long engaged the interest of physicians and pharmacologists. Several ergot alkaloids induce smooth muscle contractions. For centuries it had been observed that grazing on grass infected with ergot caused abortion in pregnant farm animals, so it is not surprising that midwives and others adopted ergot as a folk medicine, using it as both an abortifacient and a drug to accelerate to uterine contractions for women in labor (Riddle, 1997).

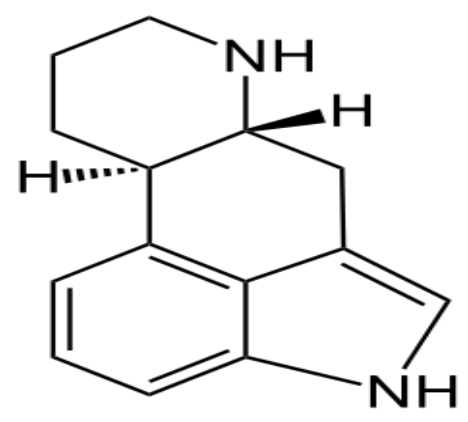

Structure of Ergot Alkaloids

\section{Patulin}

Patulin is a polyketide lactone, produced by Penicillium, Aspergillus, and other mold species that grow on fruits such as apples, pears, and grapes. The LD50 of patulin ranges from 15 to $25 \mathrm{mg} / \mathrm{kg}$ and varies with animal species and route of exposure. Toxicity includes congestion and edema of pulmonary, hepatic, and intestinal blood vessels and tissues. Sarcomas were observed when large doses of patulin were injected into animals. As a result, there have been concerns over the possibility of carcinogenicity to children and adults who drink large amounts of fruit juice, especially apple juice, for many years (FDA, 2000). WHO Codex Alimentarius Commission recommends a limit of $50 \mathrm{ug} / \mathrm{kg}$ of patulin in apple juice and cider (International Agency for Research of Cancer 1984). Patulin is degraded by sulfur dioxide or sulfide, a common food preservative for dry fruits and juices.

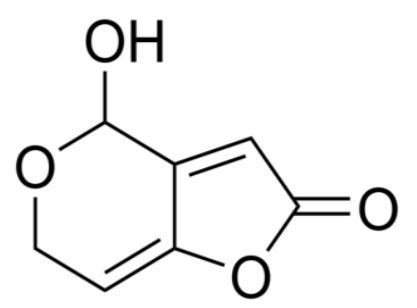

Structure of Patulin

\section{Fumonisins}

Fumonisins are group of 15 mycotoxins produced by Fusarium molds (mostly Fusarium verticilloides and Fusarium moniliforme) (IARC, 1993). The most frequently found member of this group is fumonisin B1 (FB1). It 


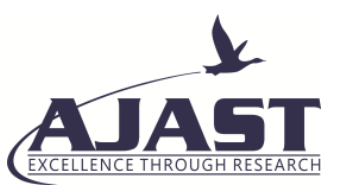

Asian Journal of Applied Science and Technology (AJAST)

Volume 5, Issue 3, Pages 43-67, July-September 2021

interferes with the metabolism of sphingolipids (Voss et al., 2007). In a single FB1-caused acute intoxication, only gastrointestinal symptoms (diarrhea, vomiting, e.t.c.) were reported. It has been implicated in sporadic animal diseases (Thiel et al., 1992), especially equine leucoencephalomalacia (ELEM). They are common contaminants of corn and maize. Although they are not as potent as aflatoxins, their concentrations frequently reach hundreds of parts per million up to $300 \mathrm{mg} / \mathrm{kg}$ of maize.

There are more than 100 secondary metabolites produced by Fusarium species, a number of which can critically affect human and animal health (Bentley and Bennett, 1999). It has been reported severally epidemics of head blight and maize ear rot of Fusarium which are common in Asia, Africa and South America where cereals are predominantly grown. Chronic exposure to FB1 is connected to a high rate of neural tube defects (brain and spinal cord malformations). Several like Kashin Beck syndrome in the USSR, China and VietNam; Mseleni joint disease in southern Africa; endemic familial arthritis in India; alimentary toxic aleukia in the USSR; and oesophageal cancer in southern Africa were linked to Fusarium toxins. Most of these mycotoxins produced by moulds that are of importance to human health are produced under poor storage conditions (Desjardins and Proctor, 2007; Adeyeye, 2016).

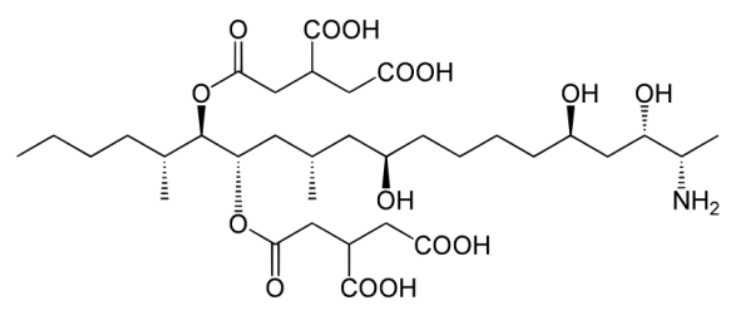

Structure of Fumonisin

\section{Zearalenone}

Zearalenone is a Fusarium metabolite with potent estrogenic activity; hence, in addition to being called (probably erroneously) a mycotoxin, it also has been labeled a phytoestrogen, a mycoestrogen, and a growth promotant. Zearalenone (ZEA) is produced by some Fusarium species (El-Nezami et al., 1998).

This is a myco toxin with low acute toxicity in experimental animals and there is no report of acute toxicity in humans. Symptoms of chronic exposure are caused by interactions of ZEA and its metabolites with estrogen receptors. Premature telarche (development of breasts in young girls) with precocious pseudopuberty has been seen in young girls in Costa Rica exposed to residues of ZEA in meat (used as a growth-promoting compound) (Solfrizzo et al., 2011). Premature telarche in girls and male gynecomastia were reported in Hungarian children consuming naturally ZEA- contaminated "healthy" food (El-Nezami et al., 2002)<smiles>C[C@H]1CCCC(=O)CCC/C=C/c2cc(O)cc(O)c2C(=O)O1</smiles>

Structure of Zearalenone 
Table 1. Physiological Aspects of Mycotoxin Exposure

\begin{tabular}{|c|c|c|c|c|c|}
\hline $\mathrm{S} / \mathrm{N}$ & Mycotoxins & $\begin{array}{l}\text { Strain, Main } \\
\text { Producer }\end{array}$ & Occurrence & $\begin{array}{c}\text { Symptoms, Signs, Toxicity } \\
\text { (Mycotoxicosis ) }\end{array}$ & Source \\
\hline 1. & Ochratoxin A & $\begin{array}{l}\text { Aspergillus } \\
\text { carbonarius, } \\
\text { Penicillium } \\
\text { verrucosum, } \\
\text { Pichia } \\
\text { verrucosum }\end{array}$ & $\begin{array}{l}\text { Cereals, coffee, } \\
\text { cocoa, wine, dried } \\
\text { fruits, beer, grape } \\
\text { juice, malt, beer, } \\
\text { bread, bakery } \\
\text { products, spices, } \\
\text { beans, liver, kidney } \\
\text { and blood of farm } \\
\text { animals, food } \\
\text { commodities of } \\
\text { animal origin }\end{array}$ & $\begin{array}{l}\text { Nephrotoxic, } \\
\text { Nephrocarcinogenic, } \\
\text { immunosuppressive, } \\
\text { carcinogenic, teratogenic, the } \\
\text { most toxic member of } \\
\text { ochratoxins }\end{array}$ & $\begin{array}{l}\text { Marin et al., } \\
2013\end{array}$ \\
\hline 2. & Aflatoxins & $\begin{array}{l}\text { Aspergillus } \\
\text { flavus, } \\
\text { A. parasiticus, } \\
\text { Aspergillus } \\
\text { nomius }\end{array}$ & $\begin{array}{l}\text { Maize, peanuts, tree } \\
\text { nuts, dried fruits, } \\
\text { milk, cereals, rice }\end{array}$ & $\begin{array}{l}\text { Carcinogenicity, } \\
\text { aflatoxicoses, immune } \\
\text { suppression, } \\
\text { hepatocarcinogens in animals } \\
\text { and humans }\end{array}$ & $\begin{array}{l}\text { Peraica et al., } \\
1999\end{array}$ \\
\hline 3. & $\begin{array}{l}\text { Fumonisins } \\
\text { (B1 and B2) }\end{array}$ & $\begin{array}{l}\text { Fusarium } \\
\text { moniliforme, } \\
\text { F.proliferatu, } \\
\text { F.verticillioides, } \\
\text { Aspergillus } \\
\text { niger }\end{array}$ & $\begin{array}{l}\text { Maize and maize } \\
\text { products }\end{array}$ & $\begin{array}{l}\text { Cancer, neural tube defects, } \\
\text { acute food-borne disease, } \\
\text { cardiovascular effects }\end{array}$ & Zain, 2011 \\
\hline 4. & Zearalenone & $\begin{array}{l}\text { Fusarium } \\
\text { graminearum, } \\
\text { F. culmorum, } \\
\text { F. heterosporum }\end{array}$ & $\begin{array}{l}\text { Corn, wheat, } \\
\text { barley, oats, } \\
\text { sorghum, vegetable } \\
\text { oil, silage, straw }\end{array}$ & $\begin{array}{l}\text { Genotoxic, toxic to } \\
\text { reproduction system, } \\
\text { oestrogenic effects, } \\
\text { haematological effects, } \\
\text { haemolysis incidence in vitro, } \\
\text { oxidative stress, endocrine } \\
\text { disruptors }\end{array}$ & $\begin{array}{l}\text { Capcarova et } \\
\text { al., } 2014\end{array}$ \\
\hline 5. & $\mathrm{~T}-2$ toxin & $\begin{array}{l}\text { Fusarium } \\
\text { sporotrichioides, }\end{array}$ & Oat, barley, maize & $\begin{array}{l}\text { Inhibition of RNA and DNA } \\
\text { synthesis, oxidative stress, } \\
\text { immunosuppressive and }\end{array}$ & $\begin{array}{l}\text { Maruniakova } \\
\text { et al., } 2014\end{array}$ \\
\hline
\end{tabular}




\begin{tabular}{|c|c|c|c|c|c|}
\hline & & F. poae & & $\begin{array}{l}\text { cytotoxic effect, inhibition of } \\
\text { steroidogenesis and } \\
\text { proliferation in porcine } \\
\text { granulosa cells, ATA }\end{array}$ & \\
\hline 6. & Deoxynivalenol & $\begin{array}{l}\text { Fusarium } \\
\text { culmorum, } \\
\text { F.graminearum }\end{array}$ & $\begin{array}{l}\text { Wheat, grains, } \\
\text { maize, barley, } \\
\text { silage }\end{array}$ & $\begin{array}{l}\text { Mutagenic and carcinogenic } \\
\text { properties, decreased } \\
\text { nutritional efficiency }\end{array}$ & $\begin{array}{l}\text { Rotter } \text { et al., } \\
1996\end{array}$ \\
\hline 7. & Patulin & $\begin{array}{l}\text { Penicillium, } \\
\text { Aspergillus, } \\
\text { Byssochlamys, } \\
\text { Eupenicillium }\end{array}$ & $\begin{array}{l}\text { Apple, apple juice } \\
\text { and products }\end{array}$ & $\begin{array}{l}\text { Inhibitory activity of many } \\
\text { enzymes, alteration of } \\
\text { immunity, macrophage } \\
\text { function, gastrointestinal } \\
\text { symptoms, kidney damage, } \\
\text { changes in femoral bone } \\
\text { structure, changes in sperm } \\
\text { motility }\end{array}$ & $\begin{array}{l}\text { Schneidgeno } \\
\text { va et al., } 2014\end{array}$ \\
\hline
\end{tabular}

Source: Marcela et al., (2016)

\section{Methods of Detecting and Analysing Mycotoxins}

There are many reasons for the presence or production of mycotoxins in our daily food or animal feed, and in many scenarios humans cannot avoid them (Peraica et al., 1999). With the development of detection technology, more than 300 mycotoxins have been isolated and studied for their chemical properties (Hao et al., 2018).

Among the many mycotoxins studied, Aflatoxin, Ochratoxin, Zearalenone, Deoxynivalenol, and Fumonisin are the most toxic, having long plagued humanity and had enormous impacts on human health and the agricultural economy (Hussein and Brasel, 2001).

Among them, Aflatoxin B1 (AFB1) is the one that has been proven to be the most carcinogenic, being targeted to the liver and having genotoxicity (Murphy et al., 2006), while Ochratoxin A is a nephrotoxin and renal cancer compound, Zearalenone produces toxicity that attacks an animal's reproductive system (Yang et al., 2018).

Recently, research into the harm to human or animal health caused by mycotoxins has become a high-profile topic (Meena et al., 2017).

In determining mycotoxins, the samples need to be pre-treated with either of the following pre-treatment methods: Liquid-Liquid Extraction (LLE), Superficial Fluid Extraction (SFE), Solid Phase Extraction (SPE); afterwhich the sample can then be separated with any of the following analytical/separation methods; Thin Layer Chromatography (TLC), High Performance Liquid Chromatography (HPLC), Gas Chromatography (GC), Enzyme-Linked Immuno Sorbent Assay (ELISA), Near-Infrared Spectroscopy (NIR), and Liquid Chromatography-Mass Spectrometry (LC-MS) (Nacher-Mestre, 2013). 


\section{Pre-Treatment Methods}

\section{Liquid-Liquid Extraction (LLE)}

This method involves exploiting the different solubility of the toxin in aqueous phase and in immiscible organic phase, to extract the compound into one solvent leaving the rest of the matrix in the other. Thus, solvents such as hexane and cyclo-hexane are used to remove non-polar contaminants, e.g. lipids and cholesterol. The procedure is effective for several toxins and works well in small-scale preparations (Bauer and Gareis, 1987). However, it is time consuming, and is dependent on which matrix is being used, and which compounds are been determined. Disadvantages lie with possible loss of sample by adsorption onto the glassware.

\section{Supercritical Fluid Extraction (SFE)}

This method uses a super critical fluid, such as $\mathrm{CO}_{2}$ to extract the required compound from the matrix. This works well due to the high solvating power and density of the solvating liquid. Supercritical fluid chromatography on fused silica capillary columns have been applied previously for separating toxins (Young and Games, 1992), but it is not a successful technique owing to the problems related to SFE (Engelhardt and Hass, 1993). This technique is not suitable for routine analysis due to high costs and the need for specialised equipment (Holcomb et al., 1996).

\section{Solid Phase Extraction (SPE)}

The basic principle of SPE technology is a variation of chromatographic techniques based around small disposable cartridges packed with silica gel, or bonded phases which are in the stationary phase. The sample is loaded in one solvent, generally under reduced pressure, rinsed, where most of the contaminants are removed, and eluted in another solvent (EMAN, 2003). These cartridges have a high capacity for binding of small molecules. The SPE systems have many advantages such as using a considerably less solvent, and their fastness in operation. Also, they can be used in pre-concentration of the samples for better detection.

\section{Separation Techniques}

\section{Thin layer chromatography (TLC)}

Thin-layer chromatography (TLC) is a technique that can be used for the separation, purity assessment, and identification of organic compounds (Betina, 1993). The most popular method used for mycotoxins analysis is TLC, which offers the ability to screen large numbers of samples economically. There are good reviews available on the applications of TLC for mycotoxin analysis (Holcomb et al., 1992). The use of TLC analysis for mycotoxins is still popular for both quantitative and semi-quantitative purposes. This is due to its high through- put of samples, low operating cost and ease of identification of target compounds. There have been uses of silica gel columns for purification of mycotoxins, example, ELISA for Aflatoxins in corn and peanuts. Silica gel layer seems to be one of the common layers used for TLC (Richardson et al., 1985).

\section{High performance liquid chromatography (HPLC)}

This is a quantitative technique that is suited for online cleanup of sample extract and could be combined with different detectors (Li et al., 2001). Most Modern analysis of mycotoxins relies heavily on HPLC employing 
various adsorbents depending on the physical and chemical structure of the mycotoxin. Most of the protocols used for HPLC detection of mycotoxins are very similar. The most commonly found detection methods are UV or fluorescence detectors, which rely on the presence of a chromophore in the molecules (Razzazi-Fazeli et al., 2002). A number of toxins already have natural fluorescence (e.g. Ochratoxin A, Aflatoxin and Citrinin) and can be detected directly in HPLC; though some mycotoxins, such as Fuminisin, lack chromophore.

\section{Gas chromatography $(G C)$}

Gas Chromatography is regularly used to identify and quantify the presence of mycotoxins in food samples (Scott, 1989). Most mycotoxins are not volatile and therefore have to be derivatised for analysis using GC. Several techniques have been developed for the derivatisation of mycotoxins. Chemical reactions such as silylation or polyfluoroacylation are employed in order to obtain a volatile material. As with other mycotoxins, Ochratoxin A cannot be directly determined by GC as it is not volatile (Scott, 1981).

\section{Capillary electrophoresis (CE)}

The individual detection ofclosely related toxins requires sophisticated separation technique in addition to high sensitivity. The effective separation of components can be based upon charge and mass dependent migration in an electrical field. The fast separations can be accomplished by capillary electrophoresis in aqueous buffer solutions, excluding the need for organic solvents (Wilkes et al., 1998).

\section{Enzyme-Linked Imuno Sorbent Assay (ELISA)}

Other separation techniques exist which are capable of running alongside or in place of chromatographic methods. Among these is ELISA which became very popular recently due to their relatively low cost and easy application (Goryacheva et al., 2007b). Commercially available ELISA kits for detection of mycotoxins are normally based on a competitive assay form that uses either a primary antibody specific for the target molecule or a conjugate of an enzyme and the required target. The complex formed will then interact with a chromogenic substrate to give a measurable result. They can be portable, rapid and are highly specific as well as simple to use (Goryacheva et al., 2007a).

\section{Health Implications of Consuming Mycotoxins-Contaminated Foods}

Mycotoxins are metabolites secreted by fungi growing on organic substrates of diverse nature which could produce fatal or side effects when ingested or consumed by humans or animals. Mycotoxins are chemical metabolites of great economic importance and health implication to both animals and humans. Aflatoxin ingestion has been implicated in hepatocellular carcinoma (liver cancer) (Adejumo and Adejoro, 2014, Williams et al., 2004), reported to be the third-leading cause of cancer worldwide according to WHO (2008), with about 600,000 fresh cases each year. Adejumo and Adejoro, 2014, Hussein and Brussel, 2001 and Zain, 2011 have reported that aflatoxin contamination reduces feed intake, increase liver and kidney weights of farm animals, as well as induce immune-suppression and hepatitis as well as high mortality in farm animals. Mycotoxins have been implicated in several countries for the outbreak of diseases. In India and Kenya mycotoxins have been implicated in the outbreak of aflatoxic hepatitis, in the outbreak of enteric ergotism in India; in the outbreak of vascular ergotism in Ethiopia; 


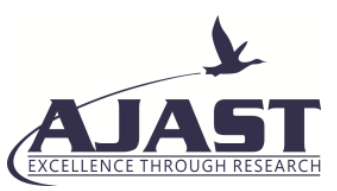

Asian Journal of Applied Science and Technology (AJAST)

Volume 5, Issue 3, Pages 43-67, July-September 2021

and in the outbreak of deoxynivalenol mycotoxicosis in India and China. The out- breaks have been linked to consumption of cereals that were grown and stored under drought and humid conditions during either the growing season or harvest or storage (Jelinek et al., 1989). Fatal effects could be vomiting, weight loss, tumors growth, and death. Several toxics secreted by fungi are well known, and majority of them occur in grain crops. Most mycotoxins affect organs in the body and could be fatal to blood, kidneys, skin, or central nervous system, and some are known carcinogens (Ashiq, 2015; Yin, et al., 2008; Martins et al., 2001). Fungi are the major source of mycotoxins in foods. Aspergillus, Penicillium, and Fusarium are the fungi of greatest importance to humans with respect to food poison by mycotoxins.

The extent of detrimental consequences of mycotoxins on the health of people or animals depend on dose and length of exposure, type of mycotoxin, physiological and dietary status, and possible synergistic outcomes of different chemical compounds to which the human beings are exposed (Gajecka et al., 2013). The study concerning the evolution of mycotoxins and mycotoxicoses is receiving considerable attention with the overall thrust for prevention of mycotoxin production and to save our food/feed products from contamination and fungi-causing mycotoxicoses.

\section{Conclusion and Recommendation}

Fungi are very important organisms and their usefulness and economic importance cannot be overstated. However, many of them produced metabolites that are poisonous or dangerous to humans and animals. These metabolites called mycotoxins are important because their implications in animal and human health are substantial and the economic importance widely studied. Unfortunately, majority of the populace in developing countries do not know the inherent dangers of consuming mouldy produce with possible contamination by mycotoxigenic fungi because of lack of awareness about the danger involved. Therefore, there is need for general and public education to sensitise the people on the economic and health hazards posed by mycotoxins.

\section{Declarations}

\section{Source of Funding}

This research did not receive any grant from funding agencies in the public, commercial, or not-for-profit sectors.

\section{Competing Interests Statement}

The authors declare no competing financial, professional and personal interests.

\section{Ethical Approval}

Ethical approval for this research was given based on institutional guidelines.

\section{Consent for publication}

Authors declare that they consented for the publication of this research work.

\section{Availability of data and material}

Authors are willing to share the data and material according to relevant needs. 


\section{References}

Abarca, M. L., Bragulat, M. R., Sastella, G. and Cabanes. F. J. (1994). Ochratoxin A production by strains of Aspergillus niger var. niger. Appl. Environ. Microbiol. 60: 2650-2652.

Abd-Elsalam, K.A and Prasad, R. (2018). Nanobiotechnology Applications in Plant Protection. Springer, p. 394.

Abramson, D., Usleber, E and Marlbauer. E. (2001). Immunochemical method for citrinin. In: Mycotoxin protocols. Humana Press, Totowa, N.J. pp. 195-204.

Adejumo, T. O and Adejoro. D. O. (2014). Incidence of aflatoxins, fumonisins, and ochratoxins in Nigerian foods and possible intervention strategies. Food Science and Quality Management. 31:127-146.

Adeyeye, S. A. (2016). Fungal mycotoxins in foods: A review, Cogent Food and Agriculture Amyot, J. 2: 121-127.

Alshannaq, A andYu, J.H. (2017). Occurrence, Toxicity, and Analysis of Major Mycotoxins in Food. Int. J. Environ. Res. Public Health.14: 632.

American Academy of Pediatrics (1998). Toxic effects of indoor molds. Pediatrics101:712-714.

Anderson, S. J. (1995). Compositional changes in surface mycoflora during ripening of fermented sausages. J. Food Protect. 58: 426-429.

Ashiq, S. (2015). Natural occurrence of mycotoxins in food and feed: Pakistan perspective. Comprehensive Reviews in Food Science and Food Safety 14: 159-175.

Barrett, J. (2000). Mycotoxins: of molds and maladies. Environ. Health Perspect. 108: A20-A23.

Bauer, J and Gareis, M. (1987). Ochratoxin A in the Nahrungsmittelkette. J. Vet. Med. Ser. 34: 613.

Bayman, P., Baker, J. L., Doster, M. A., Michailides, T. J and Mahoney. N. E. (2002). Ochratoxin production by the Aspergillus ochraceus group and Aspergillus alliaceus. Appl. Environ. Microbiol. 68: 2326-2329.

Beardall, J. M and Miller. J. D. (1994). Disease in humans with mycotoxins as possible causes, Mycotoxins in grains. Compounds other than aflatoxin. Eagan Press, St. Paul, Minn. pp. 487-539.

Belkin, L. (2001). Haunted by Mould. New York Times Magazine, Aug. 12, pp. 62, 64-65.

Bennett, J. W. (1987). Mycotoxins, mycotoxicoses, mycotoxicology and my-copathology. Myco. 100: 3-5.

Benngett, J. W and Bentley, R. (1999). Pride and prejudice: the story of ergot. Perspect. Biol. Med. 42: 333-355.

Bennett, J. W., Chang, P.K and Bhatnagar, D. (1997). One gene to whole pathway: the role of norsolorinic acid in aflatoxin research. Adv. Appl. Microbiol., 45: 1-15.

Bentley, R and Bennett, J. W. (1999). Constructing polyketides: from Collie to combinatorial biosynthesis. Annu. Rev. Microbiol. 53: 411-446.

Bennett, J.W and Klich, M. (2003). Mycotoxins, Clin. Microbiol. Rev. 16 (3): 497-516.

Berry, C. L. (1988). The pathology of mycotoxins. J. Pathol. 154: 301-311. 
Betina V. (1985). Thin-layer chromatography of mycotoxins. J Chromatogr. 334(3):211-76.

Bhat, R. V., Shetty, P. H., Amruth, R. P.and Sudershan, R. V.(1997). A foodborne disease outbreak due to the consumption of mouldy sorghum and maize containing fumonisin mycotoxins. J. Clin. Toxicol. 35: 249-255.

Blanc, P. J., Loret, M. O and Goma, G. (1995). Production of citrinin by various species of Monascus. Biotechnol. Lett. 17: 291-294.

Blout, W. P. (1961). Turkey “X” disease. Turkeys 9: 52-77.

Brakhage, A. A. (2005). Systemic fungal infections caused by Aspergillus species: Epidemiology, infection process and virulence determinants. Current Drug Targets. 6(8): 875-886.

Bressac, B., Kew, M. Wands, J and Ozturk. M. (1991). Selective G to T mutations of p53 gene in hepatocellular carcinoma from southern Africa. Nature 350:429-431.

Brown, D., McCormick, S.P., Alexander, N.A., Proctor, R. H and Desjardins, A. E. (2001). A genetic and biochemical approach to study trichoth- ecene diversity in Fusarium sporotrichioides and Fusarium graminearum. Fung. Genet. Biol. 32: 121-133.

Brown, D. H., Yu, J. H. Kelkar, H. S. Fernandes, M. Nesbitt, T. C. Keller, N. P. Adams, T. H and Leonard, T. J. (1996). Twenty-five co-regulated transcripts define a sterigmatocystin gene cluster in Aspergillus nidulans. Proc. Natl. Acad. Sci.., 93: 1418-1422.

Brown, R. L., Bhatnagar, D. Cleveland, T. E and Cary, J. W. (1998). Recent advances in preharvest prevention of mycotoxin contamination. In: K. K. Sinha and D. Bhatnagar, Mycotoxins in agriculture and food safety. Marcel Dekker, Inc., New York, USA. pp. 351-379.

Bucci, T., Hansen, D. K and LaBorde, J. B. (1996). Leucoencephalomalacia and hemorrhage in the brain of rabbits gavaged with mycotoxin fumonisin B1. Nat. Toxins 4: 51-52.

Bullerman L. B and Bianchini, A. (2007). Stability of mycotoxins during food processing. Int J. Food Microbio. 119: $140-146$.

Bunge, I., Heller, K. and Roschenthaler, R. (1979). Isolation and purification of ochratoxin A. Z. Lebensm. Unters. Forsch. 168: 457-458.

Burns, R. P and Dwivedi, P. (1986). The natural occurrence of ochratoxin A and its effects in poultry. A review. Part II. Pathology and immunology. World Poultry Sci.42: 48-62.

Granado, F.J., Viciana, P.C., E.G. Vera, M.J. Nozal, M., Opez-Cortes, L. F. (1997). Ergotism related to concurrent administration of ergotamine tartrate and ritonavir in an AIDS patient. Antimi-crob. Agents Chemother. 41: 1297. Capcarova, M., Dufalova, L., Zbynovska, K and Kalafova, A.(2014). Effect of zearalenone on haematological parameters of porcine blood in vitro. J. Microbiol. Biotechnol. Food Sci. 4(2), 185-188.

Caporael, L. R. (1976). Ergotism: the Satan loosed in Salem? Science, 192: 21-26. 
Asian Journal of Applied Science and Technology (AJAST)

Volume 5, Issue 3, Pages 43-67, July-September 2021

Carlton, W. W and Tuite, J. (1977). Metabolites of P. viridicatum Toxicology: In J. V. Rodricks, C. W. Hesseltine, and M. A. Mehlman (ed.), Mycotoxins in human and animal health. Pathotox Inc., Park For. South, Ill. pp. 525-555.

Castegnaro, M., Barsch, H and Chernozemsky, I. (1987). Endemic nephropathy and urinary tract tumors in the Balkans. Cancer Res., 47: 3606-3609.

Centers for Disease Control and Prevention, CDCP. (1994). Acute pulmonary hemorrhage/hemosiderosis among infants Cleveland, Ohio, January 1993- Noveber 1994. Morb. Mortal. Wkly. Rep. 43: 881-883.

Centers for Disease Control and Prevention. (2000). Update: pulmonary hemorrhage/hemosiderosis among infantsCleveland, Ohio, 1993-1999. Morb. Mortal. Wkly Rep. 49: 180-184.

Chu, F. S. (1991). Current Immunochemical Methods for Mycotoxin Analysis: In M. Vanderlaan, L. H. Stanker, B. E. Watkins, and D. W. Roberts. Immunoassays for trace chemical analysis: monitoring toxic chemicals in humans, food, and the environment. American Chemical Society, Washington, D.C. pp. 140-157.

Chu, F. S. (1998). Mycotoxins occurrence and toxic effect. In M. Sadler, J. J. Strain and B. Caballero Encyclopedia of human nutrition. Academic Press, New York, N.Y. pp. 858-869.

Chu, F. S. (1974). Studies on ochratoxins. Crit. Rev. Toxicol. 2: 499-524.

Chu, F. S. (1997). Trichothecene mycotoxicoses. Encyclopedia Hum. Biol. 8: 511-522.

Ciegler, A. (1986). Mycotoxins: a new class of chemical weapons. NBC De- fense \& Tech. Int., April, pp. 52-57.

Ciegler, A. (1977). Patulin, In J. V. Rodricks, C. W. Hesseltine, and M. A. Mehlman (ed.), Mycotoxins in human and animal health. Pathotox Publishers, Inc., Park Forest South,. pp. 609-624.

International Agency for Research of Cancer, IARC (1984).Monographs on the evaluation of the carcinogenic risk of chemicals to humans. Patulin. IARC; 40: 83-98.

Food and Drug Administration (FDA). (2000). Office of Plant and Dairy Food and Beverages, Center for Food Safety and Applied Nutrition. Patulin in Apple Juice, Apple Juice Concentrates and Apple Juice Products. U.S. Food and Drug Administration.

Cleveland, T. E and Bhatnagar, D. (1992). Molecular strategies for reducing Aflatoxin levels in Crops before Harvest. In: D. Bhatnagar and T. E. Cleveland (ed.), Molecular approaches to improving food quality and safety. Van Nostrand Reinhold, New York, N.Y., pp. 205-228.

Cole R. J.(1986). Etiology of Turkey 'X'disease in retrospect: A case for the involvement of cyclopiazonic acid. Mycotoxin Res., 2: 3-7.

Council for Agricultural Science and Technology, CAST. (2003). Mycotoxins: Risks in Plant, Animal, and Human Systems. Ames, IA: Task Force Report. 139.

Council for Agricultural Science and Technology. (1989). Mycotoxins. Economic and Health Risks. Council for Agricultural Science and Technology Task Force Report. No. 116. 
Council for Agricultural Science and Tech- nology, Ames, Iowa.

Creppy, E. E. (1999). Human ochratoxicosis. J. Toxicol. Toxin Rev. 18: 277-293.

Dales, R. E., Burnett, R. and Zwaneburg, H.(1991). Adverse health effects among adults exposed to home dampness and moulds. Am. Rev. Respir. Dis., 143: 505-509.

Degen, G.H., Ali, N and Gundert-Remy, U.(2018). Preliminary data on citrinin kinetics in humans and their use to estimate citrinin exposure based on biomarkers. Toxicol. Lett., 282, pp. 43-48.

Deger, G. E. (1976). Aflatoxin human colon carcinogenesis? Ann. Intern. Med. 85: 204-205.

Desjardins, A. E and Plattner, R. D. (2000). Fumonisin B (1)-nonproducing strains of Fusarium verticillioides cause maize (Zea mays) ear infection and ear rot. J. Agric. Food Chem. 48: 5773-5780.

Desjardins, A. E., Hohn, T. M and Mc Cormick, S. P.(1993). Trichothecene biosynthesis in Desjardins, A. E., Spencer, G. F., Plattner, R. D and Beremand, M. N.(1989). Furanocoumarin Fusarium species: chemistry, genetics, and significance. Microbiol. Rev. 57: 595-604. phytoalexins, trichothecene toxins and infection of Pasti- naca sativa by Fusarium sporotrichioides. Phtyopathology 79: 170-175.

Eaton, D.L., Gallagher, E. P. (1994). Mechanisms of aflatoxin carcinogenesis. Annu. Rev. Phar. Tox. 34: 135-172.

Eaton, D. L and Ramsdel, H. S. (1992). Species and diet related differences in aflatoxin biotransformation: In Handbook of applied mycology, Vol. 5, mycotoxins in ecological systems. Marcel Dekker, Inc., N.Y. pp. 157-182.

El-Nezami, H., Kankaanpaa, P. E. Salminen, S and Ahokas, J. T. (1998). Physicochemical alterations enhance the ability of dairy strains of lactic acid bacteria to remove aflatoxins from contaminated media. J. F. Prot. 61: 466-468. El-Nezami, H., Polychronaki, N. Salminen, S and Mykkanen, H. (2002). Binding rather than metabolism may explain the interaction of two food grade Lactobacillus strains with zearalenone and its derivative zearalenol. Appl. Environ. Microbiol. 68: 3545-3549.

European Mycotoxin Awareness NetworkEman. (2003). European Mycotoxin awareness network coordinated by Leatherhead Food Research Association UK. https//www.ifra.co.uk/eman/index.htm).

Engelhart, S., Loock, A., Skutlarek, D., Sagunski, H., Lommel, A., Farber, H and Exner, M. (2002). Occurrence of toxigenic Aspergillus versicolor isolates and sterigmatocystin in carpet dust from damp indoor environments. Appl. Environ. Microbiol. 68: 3886-3890.

Engelhardt, H and Hass, P. (1993). Chromatogr. Sci., 31: 13.

Environmental Protection Agency, EPA. (1991). Sick building syndrome. Indoor Air Quality Sheet 4. Environmental Protection Agency, Washington, D.C.

Escrivá, L., Font, G., Manyes, L and Berrada, H. (2017). Studies on the Presence of Mycotoxins in Biological Samples: An Overview. Toxins, 9, 251.

Etzel, R. A. (2002). Mycotoxins. J. Am. Med. Assoc. 287: 425-427. 
Evaluation of certain mycotoxins in food (Fifty-sixth report of the joint FAO/WHO expert committee on food additives). (2002). WHO Technical Report Series, No. 906.

Fink-Gremmels, J. (1999). Mycotoxins: their implications for human and animal health. Vet. Q. 21: 115-120.

Food and Agricultural Organization, FAO. (1997). Food and Agricultural Organization of the United Nations Food and Nutrition Paper. Worldwide regulations for mycotoxins. A compendium. Food and Agricultural Organization, Rome, Italy.

Forgacs, J. (1962). Mycotoxicoses-the neglected diseases. Feedstuffs 34: 124-134.

Forgacs, J. (1972). Stachybotryotoxicosis. In: Microbial toxins, vol. VI: fungal toxins. Aca. Press, NY., pp. 95-128. Forgacs, J., and Carll, W. T. (1962). Mycotoxicoses. Adv. Vet. Sci. 7: 273-382.

Fuller, J. G. (1968). The day of St. Anthony’s fire. Macmillan, New York, N.Y.

Fung, F., Clark, R and Williams, S. (1998). Stachybotrys, a mycotoxin pro- ducing fungus of increasing toxigenic importance. J. Toxicol. Clin. Toxicol. 36: 79-86.

Gajecka, M, Stopa, E, Tarasiuk, M, Zielonka, Gajecki, M. (2013). The expression of type-1 and type-2 nitric oxide synthase in selected tissues of the gastrointestinal tract during mixed mycotoxicosis, Toxins 5(11): 2281-2292.

Goryacheva, I. Y., De Saeger, S., Delmulle, B., Lobeau, M., Eremin, S. A., Barna-Vetro, I and Van Peteghem, C. (2007a). Simultaneous non-instrumental detection of aflatoxin B1 and Ochratoxin A using a clean-up tandem immunoassay column. Anal Chim Acta., 590(1): 118-124.

Goryacheva, I. Y., De Saeger, S., Nesterenko, I. S, Eremin, S. A and Van Peteghem, C. (2007b). Rapid all-in-one three-step immunoassay for non-instrumental detection of ochratoxin A in high coloured herbs and spices. Talanta 72(3): 1230-1234.

Goto, T., Wicklow, D. T and Ito, Y. (1996). Aflatoxin and cyclopiazonic acid production by a sclerotium-producing Aspergillus tamarii strain. Appl. Environ. Microbiol. 62: 4036-4038.

Graniti, A. (1972). The evolution of the toxic concept in plant pathology. In: R. K. Wood, A. Ballio, and A. Graniti, Phytotoxins in plant diseases. Academic Press, New York, N.Y. pp. 1-18.

Grove, J. F. (1968). The constituents of glutinosin. J. Chem. Soc. 7: 810-812.

Haller, J. S., Jr. (1993). Ergotism. In: K. F. Kiple (ed.), The Cambridge world history of human disease. Cambridge University Press, Cambridge, United Kingdom. pp. 718-719.

Hamilton, P. B., Huff, W. E. Harris, J. R and Wyatt, R. D.(1982). Natural occurrences of ochratoxicosis in poultry. Poult. Sci., 61: 1832-1836.

Harrison, L. R., Colvin, B. M. Greene, J. T. Newman, L. E and Cole, J. Jr. (1990). Pulmonary edema and hydrothorax in swine produced by fumonisin B1 a toxic metabolite of Fusarium moniliformes. J. Vet. Diagn. Investig. 2: 217-221. 
Hao, K. Suryoprabowo, S. Song, S. Liu L. Q and Kuang, H. (2018). Food Agric. Immunol., 29: 498-510.

Hayes, A. W. (1980). Mycotoxins: a review of biological effects and their role in human diseases. Clin. Toxicol. 17: $45-83$.

Hayes, R. B., Van Nienwenhuise, J. P. Raatgever, J. W and TenKate, F. J. (1984). Aflatoxin exposure in the industrial setting: an epidemiological study of mortality. Food Chem. Toxicol. 22: 39-43.

Hendricks, K. (1999). Fumonisins and neural tube defects in south Texas. Epidemiology. 10: 198-200.

Hendricks, K. A., Simpson, J. S and Larsen, R. D. (1999). Neural tube defects along the Texas-Mexico border, 1993-1995. Am. J. Epidemiol. 149: 1119-1127.

Hendrickse, R. G. (1997). Of sick turkeys, kwashiorkor, malaria, perinatal mortality, heroin addicts and food poisoning: research on the influence of aflatoxins on child health in the tropics. Ann. Tr. M. Parasitol. 91: 787-793.

Hendry, K. M and Cole, E. C. (1993). A review of mycotoxins in indoor air. J. Toxic. Environ. Health 38: 183-198.

Henry, S. H., Bosch, F. X and Bowers, J. C. (2002). Aflatoxin, hepatitis and worldwide liver risks, In: Mycotoxins and food safety. Kluwer Academic/Plenum Publications, New York, N.Y., pp. 229-320.

Henry, S. H., Bosch, F. X. Troxell, T. C and Bolger, P. M. (1999). Reducing liver cancer global control of aflatoxin. Science 286: 2453-2454.

Hetherington, A. C and Raistrick, H. (1931). Studies in the biochemistry of microorganisms. Part XIV. On the production and chemical constitution of a new yellow colouring matter, citrinin, produced from glucose by Penicillium citrinum Thom. Phil. Trans. R. Soc. London Ser. 220: 269-295.

Heyndrickx, E, Sioen, I, Huybrechts, B, Callebaut, A, De Henauw, S, De Saeger, S. (2015). Human biomonitoring of multiple mycotoxins in the Belgian population: Results of the BIOMYCO study. Environ. Int., 84, 82-89.

Hicks, J. K., Shimizu, K and Keller, N. P. (2002). Genetics and biosynthesis of aflatoxins and sterigmatocystin, In: F. Kempken, The mycota, vol. XI. Agricultural applications. Springer-Verlag, Berlin, Germany., pp. 55-69.

Hofmann, A. (1972). Ergot a rich source of pharmacologically active substances. In: T. Swain, Plants in the development of modern medicine. Harvard University Press, Cambridge, Mass. pp. 236-260.

Holcomb, M., Thompson J.R and Cooper, W.M. (1996). Fluids Supercrit. 9: 118.

Hsieh, D. (1988). Potential human health hazards of mycotoxins. In: S. Natori, K. Hashimoto, and Y. Ueno, Mycotoxins and phytotoxins. Third Joint Food and Agriculture Organization/W.H.O./United Nations E Program International Conference of Mycotoxins. Elsevier, Amsterdam, the Netherlands. pp. 69-80.

Hsu, I. C., Metcalf, R. A. Sun, T. Welsh, J. A. Wang, N. J and Harris, C. C. (1991). Mutational in the p53 gene in human hepatocellular carcinomas. Nature, 350: 377-378.

Hube, B. (2004). From commensal to pathogen: Stage- and tissue-specific gene expression of Candida albicans. Current Opinion in Microbiology 7(4): 336-341. 
Hult, K., Piestina, R., Habazin-Novak, V., Radic, B and Ceovic, S.(1982). Ochratoxin A in human blood and Balkan endemic nephropathy. Arch. Toxicol. 51: 313.

Hurd, R.N. (1977). Structure activity relationships in zearalenones. In: J.V.Rodricks, C.W.Hesseltine, M.A.Mehlman, Mycotoxins in human and animal health. Pathotox Pub., Inc., Park Forest South, Ill. pp. 379-391. Husman, T. (1996). Health effects of indoor air microorganisms: a review. Scand. J. Work Env. Health 22: 5-13.

Hussein, H. S and Brasel, J. M.(2001). Toxicity, metabolism, and impact of mycotoxins on humans and animals. Toxicology167:101-134.

International Agency for Research on Cancer, IARC. (2012). Improving Public Health through Mycotoxin Control; Pitt, J.I., Wild, C.P., Baan, R.A., Gelderblom, W.C.A., Miller, J., Riley, R.T., Wu, F., Eds.; IARC: Lyon, France, pp. 2214-2219.

International Agency for Research on Cancer, IARC. (1993). Some naturally occurring substances: food items and constitutents, heterocyclic aromatic amines and mycotocins. In: Report of an IARC working group on the evaluation of carcinogenic risks to humans., Lyon.

IARC; (IARC Monographs on the Evaluation of Carcinogenic Risks to Humans, vol. 56). International Agency for Research on Cancer, IARC. (1984). The evaluation of the carcinogenic risk of chemicals to humans. IARC Monograph Supplement 4. International Agency for Research on Cancer, Lyon, France.

James, R. C. (1985). General principles of toxicology, In Industrial toxicology. Van Nostrand Reinhold, New York, N.Y., pp.7-26.

Jelinek, C. P., Pohland, E and Wood, G. E.(1989). Worldwide occurrence of mycotoxins in food and feeds, an update. J. Assoc. Off. Anal. Chem. 72: 223-247.

Joffe, A. Z. (1978). Fusarium poae and F. sporotrichioides as principal causal agents of Alimentary Toxic Aleukia. In: T. D. Wyllie and L. G. Morehouse, Mycotoxic fungi, mycotoxins, mycotoxicoses, vol. 3. Marcel Dekker, New York, N.Y., pp. 21-86.

Joffe, A. Z. (1986). Fusarium species: Their Biology and Toxicology. John Wiley and Sons, New York, N.Y. 134. In: Johanning, J. 1998. Stachybotrys revisited. J. Toxicol. Clin. Toxicol., 36: 629-631.

Jonsyn-Ellis, F. E. (2000). Seasonal variation in exposure frequency and concentration levels of aflatoxins and ochratoxins in urine samples of boys and girls. Mycopathologia152: 35-40.

Kauffman, C.A. (2007). Histoplasmosis: a clinical and laboratory update. Clinical Microb. Rev., 20(1): 115-132.

Kibugu, J. K., Ngeranwa, J. J. N., Makumi, J. N., Gathumbi, J. K and Kagira, J. M. (2009). Aggravation of 443 pathogenesis mediated by ochratoxin A in mice infected with Trypanosoma brucei 444 rhodesiense. Parasitology 136: $273-281$.

Klich, M. A. (1987). Relation of plant water potential at flowering to subsequent cottonseed infection by Aspergillus flavus. Phytopathology 77: 739-741. 
Klich, M. A and Pitt, J. I.(1988). Differentiation of Aspergillus flavus from Aspergillus parasiticus and other closely related species. Trans. Br. Mycol. Soc., 91: 99-108.

Klich, M. A., Mullaney, E. J., Daly, C. B and Cary, J. W. (2000). Molecular and physiological aspects of aflatoxin and sterigmatocystin biosynthesis by A. tamarii and A. ochraceoroseus. Appl. Microbiol. Biotechnol., 53: 605-609.

Klich, M. A., Yu, J. Chang, P.-K. Mullaney, E. J. Bhatnagar, D and Cleveland, T. E. (1995). Hybridization of genes involved in aflatoxin biosynthesis to DNA of aflatoxigenic and nonaflatoxigenic aspergilli. Appl. Microbiol. Biotechnol., 44: 439-443.

Kurtz, H.J., Mirocha, J. (1978). Zearalenone (F2) induced estrogenic syndrome in swine. In: T. D. Wyllie and L. G. Morehouse, Mycotoxic fungi, mycotoxins, mycotoxicoses, vol. 2. Marcel Dekker, New York, N.Y. pp. 1256-1264. Leslie, J. F. (1996). Introductory biology of Fusarium moniliforme, In Fumonisins in food. Plenum Press, New York, N.Y., pp. 153-164.

Li, F.Q., Yoshizawa, T., Kawamura, S., Luo, S.Y and Li, Y.W. (2001). Aflatoxins and fumonisins in corn from the high-incidence area for human hepatocellular carcinoma in Guangxi, China. J. Agric. Food Chem., 49: 4122-4126. Lorenz, K. (1979). Ergot on cereal grains. Crit. Rev. Food Sci. Nutr. 11:311-354.

Maggon, K.K., Gupta, S.K., Venkitasubramanian, T.A. (1977). Biosynthesis of aflatoxins. Bact. Rev. 41: 822-855. Malir, F., Ostry, V., Pfohl-Leszkowicz, A., Malir, J and Toman, J. (2016). Ochratoxin A: 50 Years of Research. Toxins, 8(7): 191.

Manabe, M. (2001). Fermented foods and mycotoxins. Mycotoxins, 51: 25-28.

Mannon, J and Johnson, E. (1985). Fungi down on the farm. New Sci., 105: 12-16.

Marasas, W. F. O. (1996). Fumonsins: history, world-wide occurrence and on January 14, 2019 by guesthttp://cmr.asm.org/Downloaded from impact. In: L. S. Jackson, J. W. DeVries, and L. B. Bullerman, Fumonosins in food. Plenum Press, New York, N.Y., pp. 1-17.

Marasas, W. F. O. (1995). Fumonisins: their implications for human and animal health. Nat. Toxins 3: 193-198.

Marcela, C., Katarina, Z., Anna, K., Jozef, B and Peter, B. (2016). Environmental contamination by mycotoxins and their occurrence in food and feed:Physiological aspects aspect and economic approach. Journal of Environmental science and health part B. 51(4): 236-244.

Marin, S., Ramos, A.J., Cano-Sancho, G and Sanchis, V. (2013). Mycotoxins: occurrence, toxicology, and exposure assessment. Food Chem. Toxi col., 60: 218-237.

Marquardt, R. R and Frohlich, A. A. (1992). A review of recent advances in understanding ochratoxicosis. J. Anim. Sci., 70: 3968-3988.

Marshall, E. (1983). Yellow rain experts battle over corn mold. Science, 221: 526-529.

Marshall, E. (1982). Yellow rain: filling in the gaps. Science, 217: 31-34. 
Martins, M. L., Martins, H. M and Bernardo, F. (2001). Aflatoxins in spices marketed in Portugal. Food Additives and Contaminants, 18(4): 315-319.

Maruniakova, N., Kadasi, A., Sirotkin, A.V., Bulla, J and Kolesarova, A. (2014). T-2 toxin and its metabolite HT-2 toxin combined with insulin-like growth factor-I modify progesterone secretion by porcine ovarian granulosa cells. J. Environ. Sci. Health., 49(4), 404-409.

Matossian, M. K. (1989). Ergot and the Salem witchcraft affair. Am. Sci. 70: 355-357.

Matossian, M.K. (1981). Mould poisoning: an unrecognized English health problem, 1150-1800. Med. Hist. 73-84. Meena, M., Swapnil, P and Upadhyay, R. S. (2017). Sci Rep. Microchem. J., 85: 140-144.

Meisner, H and Meisner, P. (1981). Ochratoxin A, an inhibitor of renal phosphoenolpyruvate carboxylase. Arch. Biochem. Biophys. 208: 146-151.

Miller, J. D. (1992). Fungi as contaminants in indoor air. Atmosph. Environ., 26: 2163-2172.

Miller, J. D., ApSimon, J. W., Blackwell, B. A., Greenhalgh, R and Taylor, A. (2001). Deoxynivalenol: a 25 year perspective on a trichothecene of agricultural importance.In:Fusarium, Memorial Symposium. APS Press, St. Paul, Minn. pp. 310-319.

Montana, E., Etzel, A. Allen, T. Horgan, T. E and Dearborn, D. G. (1997). Environmental risk factors associated with pediatric idiopathic pulmonary hemorrhage/hemosiderosis in a Cleveland community. Pediatrics, 99: 117-24. Moss, M. O. (1996). Mycotoxins. Mycol. Res., 100: 513-523.

Murphy, P. A. Hendrich, S. Landgren C. and Bryant, C. M. (2006). Food Mycotoxins: an Update. Journal of Food Science, 71: 51-65.

Nacher-Mestre, J. Ibanez, M. Serrano, R. Perez-Sanchez J. and Hernandez, F. J. (2013). Qualitative screening of undesirable compounds from feeds to fish by liquid chromatography coupled to mass spectrometry. Agric. Food Chem., 61: 2077-2087.

Nelson, P. E., Desjardins, A. E and Plattner, R. D. (1993). Fumonisins, mycotoxins produced by Fusarium species: biology, chemistry and signifi- cance. Annu. Rev. Phytopathol. 31: 233-252.

Newberne, P. M and Butler, W. H. (1969). Acute and chronic effect of aflatoxin B1 on the liver of domestic and laboratory animals: A Review. Cancer Res., 29: 236-250.

Nielsen, K. F., Gravesen, S., Nielsen, P. A., Andersen, B., Thrane, U and Frisvad, J. C. (1999). Production of mycotoxins on artificially and naturally in- fested building materials. Mycopathologia145: 43-56.

Nielsen, K. F., Hansen, M. O., Larsen, T. O and Thrane, U. (1998). Production of trichothecene mycotoxins on water damaged gypsum boards in Danish buildings. Int. Biodeterioration Biodegradation 42: 1-7.

Omotayo, O.P., Omotayo, A.O., Mwanza, M and Babalola, O.O. (2019). Prevalence of Mycotoxins and Their Consequences on Human Health. Toxicol. Res., 35: 1-7. 
Palmgren, M. S and Hayes, A. W. (1987). Aflatoxins in Food. In: Mycotoxins in food, Cambridge, MA: Academic Press P. Krogh, pp. 65-95.

Pandya, J.P. Arade, P.C. (2016). Mycotoxin: a devil of human, animal and crop health. Adv. Life Sci., 5: 3937-3941.

Payne, G and Brown, M. P.(1998). Genetics and physiology of aflatoxin biosynthesis. Annu. Rev. Plant Pathol., 36: 329-362.

Peers, F. G and Linsell, C. A.(1973). Dietary aflatoxins and human liver cancera population study based in Kenya. Br. J. Cancer., 27: 473-484.

Peraica M, Rašić D. (2012). The impact of mycotoxins on human history. Arh Hig Rada Toksikol., 63: 511-6.

Peraica, M., Radic, B., Lucic, A and Pavlovic, M. (1999). Toxic effect of mycotoxins in humans. Bulletin of the World Health Org., 77(9): 754-766.

Peraica M, Radic B., Lucic A and Pavlovic M. (2016). Toxic effects of mycotoxins in humans. Bulletin 477 of the World Health Organization, 77: 754-766.

Peraica, M, Radic, B, Lucic, A, Pavlovic, M. (1999). Toxic effects of mycotoxins in humans. Bull. WHO 754-766. Pestka, J. J and Bondy, G. S. (1994). Immunotoxic effects of mycotoxins. Mycotoxins in grain. other than aflatoxins. Eagan, St. Paul, Minn., pp. 339-358.

Pinotti, L., Ottoboni, M., Giromini, C., Dell'Orto, V., Cheli, F. (2016). Mycotoxin in the EU Feed Supply Chain: A Focus on Cereal Byproducts. Toxins, 8,45 .

Plattner, R. D., Weisleder, D and Poling, S. M. (1996). Analytical determination of fumonisins and other metabolites produced by Fusarium monili- forme and related species on corn. Adv. Exp. Med. Biol., 392: 57-64.

Plumlee, K. H and Galey, F. D. (1994). Neurotoxic mycotoxins: A review of fungal toxins that cause neurological disease in large animals. J. Vet. Intern. Med., 8: 49-54.

Pringle, P. (1985). Political Science. Atlantic Monthly. pp. 67-81.

Probst, C., Njapau, H and Cotty, P. J. (2007). Outbreak of an acute aflatoxicosis in Kenya in 2004: 475 identification of the causal agent. Applied and Environmental Microbiology, 73: 2762-2764.

Razzazi-Fazeli, E., Rabus, B., Cecon, B and Bohm J. (2002). Simultaneous quantification of A-trichothecene mycotoxins in grains using liquid chromatography-atmospheric pressure chemical ionisation mass spectrometry. J. Chromatogr A., 968: 129-42.

Rheeder, J. P., Marasas, W. F and Vismer, H. F.(2002). Production of fumonisin analogs by Fusarium species. Appl. Environ. Microbiol., 68: 2102-2105.

Richard, J. L., Plattner, R. D., May, J and Liska, S. L.(1999). The occurrence of ochratoxin A in dust collected from a problem household. Mycopathologia, 146: 99-103. 
Richardson, K.E., Hagler, W.M and Mirocha, C.J. (1985). Agriculture. Food Chem. 33: 862.

Riddle, J. M. (1997). Eve's herbs. A history of contraception and abortion in the west. Harvard University Press, Cambridge, Mass.

Riley, R. T and Goeger, D E. (1992). Cyclopiazonic acid: speculations on its function in fungi. In: Handbook of applied mycology, vol. 5. Mycotoxins in ecological systems. Marcel Dekker, Inc., New York, N.Y., pp. 385-402.

Robens, J. F and Richard, J. L. (1992). Aflatoxins in animal and human health. Rev. Environ. Contam. Toxicol., 127: 69-94.

Ross, R. K., Yuan, J. M. Yu, M. C. Wogan, G. N. Qian, G. S. Tu, J. T. Groopman, J. Gao, Y. T and Henderson, B. E. (1992). Urinary aflatoxin biomarkers and risk of hepatocellular carcinoma. Lancet, 339: 1413-1414.

Rotter, B. A., Prelusky, D. B and Pestka, J. J. (1996). Toxicology of deoxynivalenol (vomitoxin). J. Toxicol. Environ. Health., 48: 1-34.

Rushing, B.R and Selim, M.I. (2019). Aflatoxin B1: A review on metabolism, toxicity, occurrence in food, occupational exposure, and detoxification methods. Food Chem. Toxicol., 124, 81-100.

Sansing, G. A., E. B. Lillehoj, and R. W. Detroy. (1976). Synergistic toxic effect of citrinin, ochratoxin A and penicillic acid in mice. Toxicon, 14: 213-220.

Schneidgenova, M., Kalafova, A., Emrichova, J., Zbynovska, K., Pet-ruska, P., Ondruska, L., Jurcık, R., Chrastinov, L and Capcarova, M. (2014).The effect of patulin on rabbit sperm motility and progressive motility. J. Microbiol. Biotechnol. Food Sci., 3(2), pp. 155-156.

Schoental, R. (1984). Mycotoxins and the Bible. Perspect. Biol. Med. 28: 117-120.

Schoental, R. (1983). Precocious sexual development in Puerto Rico and oestrogenic mycotoxins (zearalenone). Lancet, 1: 537.

Schwartz, G. G. (2002). Hypothesis: does ochratoxin A cause testicular cancer? Cancer Causes Control 13: 91-100. Scott, P.M. (1989). The natural occurrence of trichothecenes, In V. H. Beasley (ed.), Trichothecene mycotoxicosis: pathophysiologic effects, Vol. I. CRC Press, Boca Raton, Fla. pp. 1-26

Scott, P. M. (1981). Toxins of Penicillium species used in cheese manufacture. J. Food Prot., 44: 702-710.

Shephard, G.S (2009). Aflatoxin analysis at the beginning of the twenty-first century. Anal. Bioanal. Chem., 395, 1215-1224.

Shier, W. T. (1998). Estrogenic mycotoxins. Rev. Med. Vet. 149: 599-604.

Simon-Nobbe, B., Denk, U., Poll, V., Rid, R and Breitenbach, M. (2008). The spectrum of fungal allergy. International Archives of Allergy and Immunology, 145 (1): 58-86.

Sinha, K. K and Bhatnagar, D. (1998). Mycotoxins in Agriculture and Food Safety. Marcel Dekker, Inc., New York, N.Y. 
Smith, J. E., Solomons, G. Lewis, C and Anderson, J. C. (1995). Role of mycotoxins in human and animal nutrition and health. Nat. Toxins., 3: 187-192.

Solfrizzo, M., Gambacorta, L and Visconti, A. (2014). Assessment of Multi-Mycotoxin Exposure in Southern Italy by Urinary Multi-Biomarker Determination. Toxin, 6: 523-538.

Solfrizzo, M., Gambacorta, L., Lattanzio, V.M.T., Powers, S and Visconti, A. (2011). Simultaneous LC-MS/MS determination of aflatoxin M1, ochratoxin A, deoxynivalenol, deepoxydeoxynivalenol, $\alpha$ and $\beta$-zearalenols and fumonisin B1 in urine as a multi-biomarker method to assess exposure to mycotoxins. An. Bio. Chem., 2831-2841.

Soto, J.B., Ruiz, M. J., Manyes, L and Juan-García, A. (2015). Blood, breast milk and urine: Potential biomarkers of exposure and estimated daily intake of ochratoxin A: A review. Food Addit. Contam., 33, 313-328.

Spanos, N. P and Gottlieb, J. (1976). Ergotism and the Salem Village witch trials. Science 194: 1390-1394.

Squire, R. A. (1981). Ranking animal carcinogens: a proposed regulatory approach. Science, 214: 877-880.

Stafford, M. E and McLaughlin, C. S.(1973). Trichodermin, a possible inhibitor of the termination process of protein synthesis. J. Cell Physiol., 82: 121-124.

Sternberg, S. (1994). The emerging fungal threat. Science, 266: 1632-1634.

Stone, R. (2001). Down to the wire on bioweapons talks. Science, 293: 414-416.

Stone, R. (2002). Peering into the shadows: Iraq’s bioweapons program. Science, 2 97: 1110-1112.

Thiel, P. G., Marasas, W. F. O., Sydenham, E. W., Shepherd, G. S, and Gelderblom, W. C. (1992).The implications of naturally occurring levels of fumonisins in corn in human and animal health. Mycopathologia, 117(1): 3-9.

Townsend (1997). Progress towards a biosynthetic rationale of the aflatoxin pathway. Pure App. Che., 58: 227-238. Trail, F., Mahanti, N and Lin, J. (1995). Molecular biology of aflatoxin biosynthesis. Microbiology 141: 755-765.

Turner, N.W., Bramhmbhatt, H., Szabo-Vezse, M., Poma, A.,Coker, R and Piletsky, S.A. (2015). Analytical methods for determination of mycotoxins: An update (2009-2014). Anal. Chim. Acta., 901, 12-33.

Ulrich, R. F and Patten, B. M. (1991). The rise, decline, and fall of LSD. Perspect. Biol. Med., 34: 561-578.

Utian, W. H. (1973). Comparative trial of P1496, a new non-steroidal oestrogen analogue. Br. M. J., 1: 579-581.

Voss, K. A., Smith, G. W and Haschek, W. M. (2007). Fumonisins: toxicokinetics, mechanism of action and toxicity. Anim Feed Sci Technol., 137: 299-325.

Wilkes, J.G and Sutherland, J.B. (1998). Sample preparation and high resolution separation of mycotoxins possessing carboxyl groups. J. Chromatogr.717: 135.

World Health Organization and Joint FAO/WHO (2017). Expert Committee on Food Additives Evaluation of certain contaminants in Food: Eighty-third report of the Joint FAO/WHO Expert Committee on Food Additives. In World Health Organization Technical Report Series; World Health Organization: Geneva, Switzerland, pp. 1-182. 
Willis, R. M., Mulvihill, J. J andHoofnagle, J. H. (1980). Attempted suicide with purified aflatoxin. Lancet, 1: 1198-1199.

Williams, J.H., Phillips, T.D., Jolly, P.E., Stiles, J.K., Jolly, C.M and Aggarwal, D. (2004). Aflatoxicosis in developing countries: A review of toxicology, exposure, potential health consequences, and interventions. Am. J. Clin. Nutr., 80, 1106-1122.

Wilson, D. M and Payne, G. A. (1994). Factors affecting Aspergillus flavus group infection and aflatoxin contamination of Crops, In D. L Eaton and J. D. Groopman, The toxicology of aflatoxins. Human health, veterinary and agricultural significance. Academic Press, San Diego, Calif., pp. 309-325.

Wilson, D. M., Mubatanhema, W and Jurjevic, Z. (2002). Biology and Ecol ogy of mycotoxigenic species as related to economic and health concerns, In J. W. deVries, M..Trucksess, and L. S. Jackson (ed.), Mycotoxins and food safety. Kluwer Academic Plenum Publications, Dordrecht, the Netherlands, pp. 3-17.

Woolf, L. I. (1986). The heterozygote advantage in phenylketonuria. Am. J. Hum. Genet., 38: 773-775.

Wu, F. (2013). Aflatoxin exposure and chronic human diseases: estimates of burden of disease. In: Unnevehr L, Grace D, editors. Aflatoxins finding solutions for improved food safety, pp. 450

Yang, S., Yi, X., Mao, X., Liu, Y., Zhang S and Li, Y. (2018). Food Agric. Immunol., 29: 615-624.

Yin, Y. N., Yan, L. Y., Jiang, J. H and Ma, Z. H.(2008). Biological con- trol of aflatoxin contamination of crops. Journal of Zhejiang University Science B 9 (10): 787-792.

Yoder, O. C. (1980). Toxins in pathogenesis. Annu. Rev. Phytopathol.,18: 103-129.

Young, J.C and Games, D.E. (1992). Chromatography, Science, 627: 247.

Yu, J., Chang, P.K., Bhatnagar, D. and Cleveland, T. E. (2000). Genes encoding cytochrome P450 and monooxygenase enzymes define one end of the afla- toxin pathway gene cluster in Aspergillus parasiticus. Appl. Microbiol. Biotechnol., 53: 583-590.

Yu, J., Woloshuk, C. P., Bhatnagar, D and Cleveland, T. E. (2000). Cloning and characterization of avfA and omtB genes involved in aflatoxin biosyn- thesis in three Aspergillus species. Gene, 248: 157-167.

Zain, E. M. (2011). Impact of mycotoxins on humans and animals. J. of Saudi Chemical Society, 15(2): 129-144. Zhang, Y. Y., Pei, F., Fang, Y., Li, P., Zhao, Y., Shen, F., Zou Yand Hu, Q. H. (2019). Food Chem., 275, 763-769. Zilinskas, R. A. (1997). Iraq's biological weapons. The past as future? J. Am. Med. Assoc. 276: 418-424. 